\title{
Oxidative stability of tilapia feeds containing Saccharomyces cerevisiae and Spirulina platensis
}

\section{Thiago Luís Magnani Grassi ${ }^{1 *}$ (D) Juliana Sedlacek-Bassani ${ }^{1}$ Elisa Helena Giglio Ponsano ${ }^{1}$ (D)}

${ }^{1}$ Faculdade de Medicina Veterinária, Universidade Estadual Paulista Júlio de Mesquita Filho (UNESP), 16050680, Araçatuba, SP, Brasil. E-mail: thiago.grassi@unesp.br. "Corresponding author.

ABSTRACT: The aim of this study was to evaluate the effect of the inclusion of microbial biomass on the oxidative rancidity of tilapia rations stored for 12 months. Treatments included a control diet and diets supplemented with either $0.01 \%$ vitamin E, 0.25 and $0.5 \%$ of Saccharomyces cerevisiae and 0.25 and $0.5 \%$ of Spirulina platensis. Experimental diets were stored in the dark inside plastic bags at room temperature $\left(25^{\circ} \mathrm{C}\right)$ for 12 months. The oxidative rancidity was measured as thiobarbituric acid reactive substances (TBARS). It was concluded that the inclusions of Spirulina platensis at $0.25 \%(1.734 \pm 0.206)$ and $0.5 \%(1.629 \pm 0.181)$ and Saccharomyces cerevisiae at $0.5 \%(1.459 \pm 0.305)$ minimized the oxidative rancidity in comparation to control diet (2.843 \pm 0.109$)$ of Nile tilapia until 12 months of storage.

Key words: biomass, lipid oxidation, ratio, TBARS.

Estabilidade oxidativa de rações de tilápia contendo Saccharomyces cerevisiae e Spirulina platensis

RESUMO: O objetivo deste estudo foi avaliar o efeito da inclusão de biomassa microbiana sobre a rancidez oxidativa de rações de tilápia armazenadas por 12 meses. Os tratamentos incluiram uma dieta controle e dietas suplementadas com 0,01\% de vitamina E 0,01\%, com 0,25 e $0,5 \%$ de S. cerevisiae e com 0,25 e 0,5\% de S. platensis. As dietas experimentais foram armazenadas em sacos plásticos escuros, em temperatura ambiente $\left(25^{\circ} \mathrm{C}\right)$, durante 12 meses. A rancidez oxidativa foi mensurada pelas substâncias reativas ao ácido tiobarbitúrico (TBARS). Concluiu-se

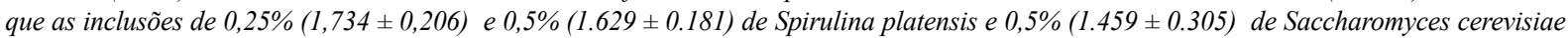
reduziram a rancidez das dietas em comparação a dieta controle de tilápias-do-Nilo após 12 meses de armazenamento.

Palavras-chave: biomassa, oxidação lipídica, ração, TBARS

Oxidative rancidity or lipid oxidation refers to the lipid deterioration featured by the formation of chemicals that change food aroma and taste, decreasing palatability and nutritional value of diets (LAGUERRE et al., 2007). The process consists of a complex chain of reactions induced by oxygen in the presence of catalysts such as heat, free radicals, light, pigments and metallic ions (LAGUERRE et al., 2007). The first stage of the chain (initiation phase) occurs with the formation of free radicals under conditions favored by light and heat and is followed by the formation of primary products (propagation phase), especially peroxides and hydroperoxides. The latter, when exposed to prolonged oxidation conditions, give rise to side products like aldehydes, ketones, epoxides, hydroxy compounds, oligomers and polymers (termination phase). Malonaldehyde (MDA) is one of the main aldehydes originated in the process and commonly used as a marker to quantify the reaction (BARRIUSO et al., 2013).

The stability of animal feed during storage is associated with lipid oxidation and so explains the use of antioxidants to slow down the process, increase the shelf life of the product, reduce the waste of raw materials and increase the range of fats that can be used in the formulation of diets, especially those of high energy (AKLAKUR, 2018).

Synthetic vitamin E may be used to prevent rancidity in fish feeds; although, butylated hydroxytoluene (BHT), butylated hydroxyanisole (BHA), tert-butyl hydroquinone (TBHQ), propyl gallate (PG) and ethoxyquinone (EQ) are the most widely used sources of additives for that purpose (AKLAKUR, 2018). However, these latter compounds may pose a risk to the health of animals and consumers since toxic and carcinogenic effects are assigned to them (PONCE-PALAFOX et al., 
2004), thus giving rise to a growing demand for antioxidants of natural origin. Two microbial biomasses (MB) with antioxidant potential stand out as fish feed ingredients. Saccharomyces cerevisiae yeast is used in the preparation of various products (e.g. ethanol) and marketed as a coproduct at the end of processes. The yeast biomass contains proteins, vitamins such as $\mathrm{E}$ and complex B, enzymes, volatile fatty acids, chelated minerals, natural antibiotics and peptides (RAN et al., 2016). Spirulina (Arthrospira) platensis biomass contains proteins, vitamins, essential amino acids, minerals, essential fatty acids and pigments, such as carotenoids and phycocyanins, which impart it high nutritional value and antioxidant properties (MORIST et al., 2001; LI et al., 2003). The microalga is able to grow on different substrates, including industrial effluents and simple and lowcost culture media, making its production totally viable (ARRUDA et al., 2006).

The purpose of this study was to evaluate the effect of microbial biomasses on the oxidative rancidity of tilapia rations stored for 12 months.

The study adopted a completely randomized design with six treatments and three replicates. Treatments included a control basal diet $(C D)$ and five diets supplemented with either $0.01 \%$ vitamin E (VE), or $S$. cerevisiae at $0.25 \%$ (SC25) and $0.5 \%$ (SC50) or S. platensis at $0.25 \%$ (SP25) and $0.5 \%$ (SP50). The calculated and analyzed values of the nutrients in the diets are presented in table 1 . The proximate composition of the biomasses were: $4 \%$ moisture, $45 \%$ protein, $0.2 \%$ lipid and $5 \%$ ash for S. cerevisiae; and $6 \%$ moisture, $46 \%$ protein, $3 \%$ lipid and $8 \%$ ash for $S$. platensis. The biomasses were dissolved in soy oil and incorporated to the basal diet inside a Y-shaped mixer. The same amount of soy oil was added to the control group. The experimental diets were stored in the dark inside plastic bags (polypropylene) at room temperature $\left(25^{\circ} \mathrm{C}\right)$ for 12 months.

For the thiobarbituric acid reactive substances (TBARS) quantification, $1 \mathrm{~g}$ of feed was homogenized with $25 \mathrm{ml}$ of $7.5 \%$ trichloroacetic acid using turrax for $1 \mathrm{~min}$ (TBARS extraction). Then, the mixture was filtered and $5 \mathrm{ml}$ of the extract were transferred to a tube containing $5 \mathrm{ml}$ $0.02 \mathrm{M}$ thiobarbituric acid. The tubes were heated in boiling water bath $\left(100{ }^{\circ} \mathrm{C}\right)$ for $40 \mathrm{~min}$ and cooled in running water for $10 \mathrm{~min}$. The TBARS were measured at $538 \mathrm{~nm}$ and the values were expressed as $\mathrm{mg}$ malonaldehyde/kg (GRASSI et al., 2016, 2018).
All data collected were subjected to analysis of variance and the significance of differences between means was tested by Tukey's test, using Action version 3.1 ${ }^{\circledR}$. Broken line regression was used to estimate the biomass requirements to avoid the oxidative rancidity as a function of MB inclusion, using PPM (Practical Program for Modeling, https://sites.google. com/site/programapraticodemodelagem/). The significance level was set at 0.05 .

The SC50, SP25 and SP50 had lower TBARS than the control group while SC25 and VE were not able to prevent the lipid oxidation during the storage for 12 months (Table 2). The antioxidant activity of biomass minimized the oxidative rancidity, increasing the shelflife of Nile tilapia feed. This effect may be assigned to carotenoids and phycocyanins in Spirulina platensis and to rutin, hesperidin, sakuranetin, quercetin, naringin, naringenin and vitamin $\mathrm{E}$ in Saccharomyces cerevisiae (SOARES et al., 2005). The inclusion of $S$. cerevisiae at $0.25 \%$ (SC25) had insufficient antioxidant activity to reduce the oxidative rancidity. The broken line regression indicated that $0.4392 \%$ S. cerevisiae (Figure. 1.A) and $0.2852 \%$ S. platensis (Figure. 1.B) biomasses in the rations are enough to provide the lowest TBARS in the diets.

GRASSI et al. (2016) also reported a delay in tilapia diets stored until 12 months when a bacterial biomass (Rubrivivax gelatinosus) was added up to $0.14 \%$ and assigned the effect to the presence of carotenoids in the biomass.

The need to seek alternatives to the synthetic antioxidant substances has increased the interest for the production of natural antioxidants through biotechnology. For instance, microbial biomasses of yeast Phaffia rhodozyma and microalgae Haematococcus pluvialis and Dunaliella salina have been used as sources of carotenoids in the feed of aquatic animals (PONCE-PALAFOX et al., 2004). Vitamin E produced by microorganisms also has been used in fish diets to prevent the oxidative rancidity and protect the tissue integrity of several fish species (PENG et al., 2009). Although, the antioxidant activity of vitamin $\mathrm{E}$ in feed is recognized, in this experiment, it was not able to prevent the lipid oxidation like the biomasses did.

More than benefits to the preservation of the ration, $S$. platensis and $S$. cerevisiae biomasses can improve fish health and meat quality. GRASSI et al. (2018) included microbial biomasses in tilapia diets and reported an improvement in the 
Table 1 - Experimental diet for tilapias.

\begin{tabular}{|c|c|c|c|c|c|c|}
\hline Ingredients (\%) & $\mathrm{CD}$ & VE & $\mathrm{SC} 25$ & SC50 & SP25 & SP50 \\
\hline Feather meal & 2 & 2 & 2 & 2 & 2 & 2 \\
\hline Ground corn & 33.06 & 33.05 & 33.06 & 33.06 & 33.06 & 33.06 \\
\hline Poultry meal by-products & 6 & 6 & 6 & 6 & 6 & 6 \\
\hline Soybean meal & 10.44 & 10.44 & 10.19 & 9.94 & 10.19 & 9.94 \\
\hline Wheat meal & 15.88 & 15.88 & 15.88 & 15.88 & 15.88 & 15.88 \\
\hline Meat meal & 17.14 & 17.14 & 17.14 & 17.14 & 17.14 & 17.14 \\
\hline Blood meal & 12 & 12 & 12 & 12 & 12 & 12 \\
\hline $\mathrm{NaCl}$ & 0.8 & 0.8 & 0.8 & 0.8 & 0.8 & 0.8 \\
\hline Chicken oil & 2 & 2 & 2 & 2 & 2 & 2 \\
\hline Premix $^{a}$ & 0.6 & 0.6 & 0.6 & 0.6 & 0.6 & 0.6 \\
\hline Methionine & 0.08 & 0.08 & 0.08 & 0.08 & 0.08 & 0.08 \\
\hline Vitamin E & 0 & 0.01 & 0 & 0 & 0 & 0 \\
\hline S. cerevisiae & 0 & 0 & 0.25 & 0.5 & 0 & 0 \\
\hline S. platensis & 0 & 0 & 0 & 0 & 0.25 & 0.5 \\
\hline Total & 100 & 100 & 100 & 100 & 100 & 100 \\
\hline \multicolumn{7}{|c|}{ 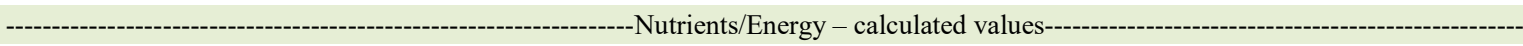 } \\
\hline Digestible energy $(\mathrm{kcal} / \mathrm{kg})$ & 3000 & 3000 & 3000 & 3000 & 3000 & 3000 \\
\hline Digestible protein $(\%)$ & 27.63 & 27.63 & 27.63 & 27.63 & 27.63 & 27.63 \\
\hline Ether extract $(\%)$ & 7.50 & 7.50 & 7.50 & 7.50 & 7.50 & 7.50 \\
\hline Crude fiber $(\%)$ & 3.00 & 3.00 & 3.00 & 3.00 & 3.00 & 3.00 \\
\hline Mineral composition (\%) & 10.48 & 10.48 & 10.48 & 10.48 & 10.48 & 10.48 \\
\hline Total calcium $(\%)$ & 2.74 & 2.74 & 2.74 & 2.74 & 2.74 & 2.74 \\
\hline Total phosphorus (\%) & 1.57 & 1.57 & 1.57 & 1.57 & 1.57 & 1.57 \\
\hline Starch $(\%)$ & 27.03 & 27.03 & 27.03 & 27.03 & 27.03 & 27.03 \\
\hline Available phosphorus (\%) & 0.69 & 0.69 & 0.69 & 0.69 & 0.69 & 0.69 \\
\hline Arginine $(\%)$ & 1.80 & 1.80 & 1.80 & 1.80 & 1.80 & 1.80 \\
\hline Lysine (\%) & 2.33 & 2.33 & 2.33 & 2.33 & 2.33 & 2.33 \\
\hline Threonine (\%) & 1.25 & 1.25 & 1.25 & 1.25 & 1.25 & 1.25 \\
\hline Tryptophan (\%) & 0.34 & 0.34 & 0.34 & 0.34 & 0.34 & 0.34 \\
\hline Methionine (\%) & 0.45 & 0.45 & 0.45 & 0.45 & 0.45 & 0.45 \\
\hline Vitamin C (mg/kg) & 700 & 700 & 700 & 700 & 700 & 700 \\
\hline \multicolumn{7}{|c|}{ - } \\
\hline Protein & 32.29 & 32.18 & 32.26 & 32.22 & 32.41 & 32.34 \\
\hline Ether extract & 8.11 & 8.15 & 8.14 & 8.11 & 8.18 & 8.09 \\
\hline Ash & 9.79 & 9.84 & 9.68 & 9.82 & 9.69 & 9.84 \\
\hline Crude fiber & 3.62 & 3.65 & 3.57 & 3.72 & 3.62 & 3.59 \\
\hline Moisture & 10.75 & 10.63 & 10.65 & 10.85 & 10.93 & 10.86 \\
\hline
\end{tabular}

$\mathrm{CD}$ - control diet, VE - CD + 0.01\% vitamin E, SC25 - CD + 0.25\% S. cerevisiae, SC50 - CD + 0.5\% S. cerevisiae, SP25 - CD + 0.25\% S. platensis and SP50 - CD + 0.5\% S. platensis. ${ }^{\mathrm{a}}$ Composition per kg of product - Choline 83,333 mg, vitamin A 2,083 UI, vitamin D3 500 UI, vitamin E 37,500 mg, vitamin K3 2,500 mg, vitamin B1 4,167 mg, vitamin B2 4,167 mg, vitamin B6 3,333 mg, vitamin B12 $7,500 \mu \mathrm{g}$, niacin $12,500 \mathrm{mg}$, calcium pantothenate $8,152 \mathrm{mg}$, pantotenic acid 7,500 mg, folic acid $833 \mathrm{mg}$, biotin $125 \mathrm{mg}$, vitamin C $116,667 \mathrm{mg}$, inositol 12,500 mg, iron specific source 12,500 mg, Fe 12,500 mg, Cu 2,500 mg, Mn 7,500 mg, Zn 16,667 mg, Co $42 \mathrm{mg}, \mathrm{I}$ $125 \mathrm{mg}$, Se $67 \mathrm{mg}$.

oxidative status of the animals and a delay in the fillets oxidation up to 60 days of storage. Moreover, S. platensis biomass increased redness and carotenoids in the tilapia fillets, so improving sensory and functional properties of the flesh (GRASSI et al., 2018).
Results presented herein indicated that $S$. cerevisiae and $S$. platensis biomasses can be considered as natural alternatives to replace the synthetic antioxidants currently in use. It was concluded that the inclusions of Spirulina platensis at 0.25 and $0.5 \%$ and Saccharomyces cerevisiae at $0.5 \%$ 
Table 2 - Oxidative rancidity of feed containing microbial biomass.

\begin{tabular}{|c|c|}
\hline Treatment & TBARS $^{*}$ (mg malonaldehyde $\mathrm{kg}^{-1}$ ) \\
\hline $\mathrm{CD}$ & $2.483 \pm 0.109^{\mathrm{a}}$ \\
\hline VE & $1.941 \pm 0.158^{\mathrm{ab}}$ \\
\hline $\mathrm{SC} 25$ & $1.900 \pm 0.019^{\mathrm{ab}}$ \\
\hline SC50 & $1.459 \pm 0.305^{\mathrm{b}}$ \\
\hline SP25 & $1.734 \pm 0.206^{\mathrm{b}}$ \\
\hline SP50 & $1.629 \pm 0.181^{b}$ \\
\hline $\mathrm{P}$ & 0.0155 \\
\hline CV (\%) & 19.6 \\
\hline
\end{tabular}

${ }^{*}$ Thiobarbituric acid reactive substances; CD - control diet, VE - CD + 0.01\% vitamin E, SC25 - CD + 0.25\% S. cerevisiae, SC50 - CD + $0.5 \%$ S. cerevisiae, SP25 - CD $+0.25 \%$ S. platensis and SP50 - CD $+0.5 \%$ S. platensis. $C V$ - coefficient of variation; ${ }^{\text {ab }}$ Means followed by different letters are significantly different $(\mathrm{P}<0.05)$.

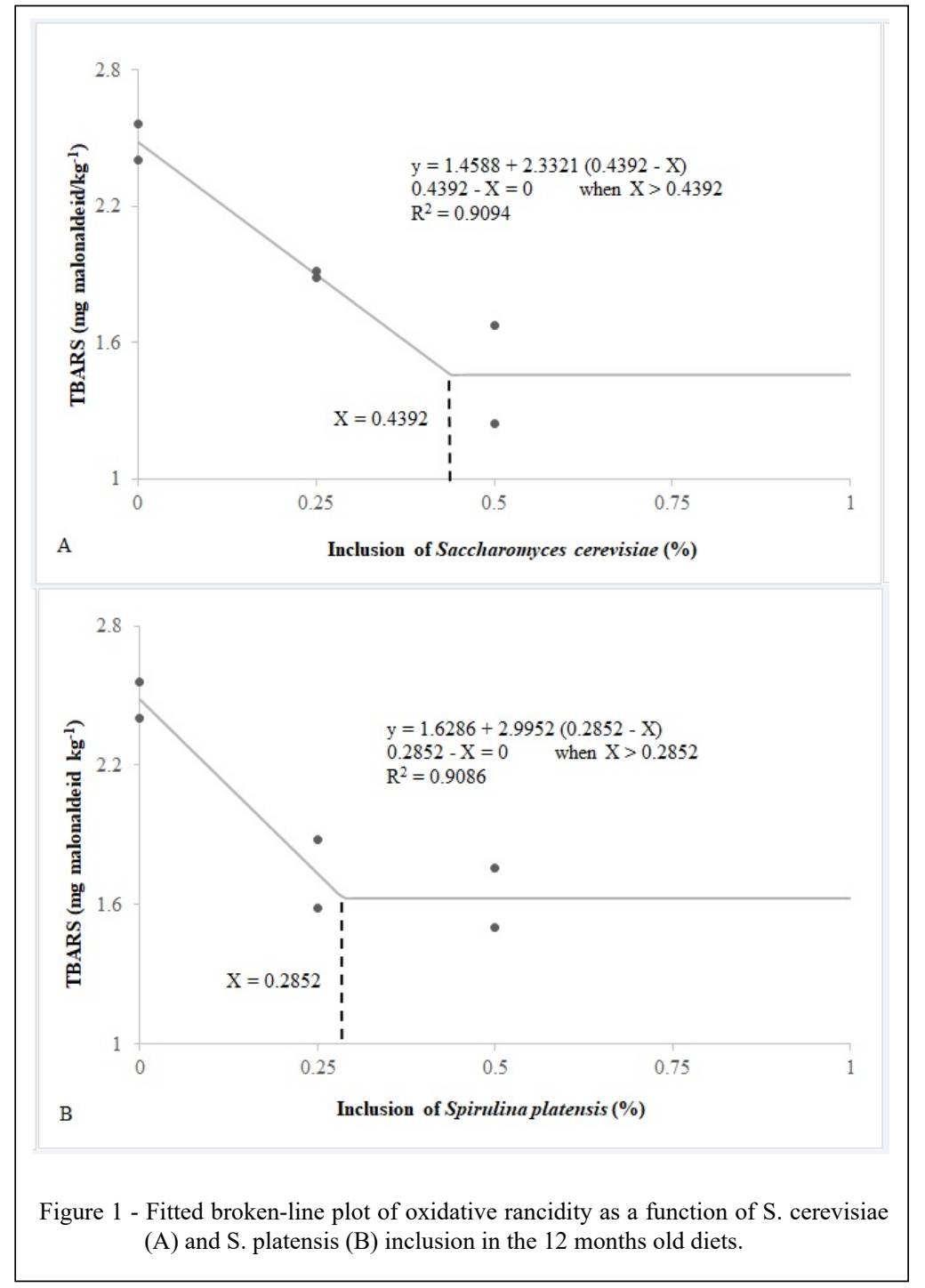

Ciência Rural, v.50, n.1, 2020. 
minimized the oxidative rancidity in Nile tilapia diets until 12 months of storage.

\section{ACKNOWLEDGEMENTS}

Authors thank CAPES (88881.134883/2016-01) for the scholarship and Fundação de Amparo à Pesquisa do Estado de São Paulo (FAPESP) for the financial support (2015/25853-1) and scholarship (2015/21216-7).

\section{DECLARATION OF CONFLICT OF INTERESTS}

The authors declare no conflict of interest. The founding sponsors had no role in the design of the study; in the collection, analyses, or interpretation of data; in the writing of the manuscript, and in the decision to publish the results.

\section{AUTHORS' CONTRIBUTIONS}

All authors contributed equally for the conception and writing of the manuscript. All authors critically revised the manuscript and approved of the final version.

\section{REFERENCES}

AKLAKUR, M. Natural antioxidants from sea: a potential industrial perspective in aquafeed formulation. Reviews in Aquaculture v.0, p.385-399, 2018. Available from: <http://dx.doi.org/10.1111/ raq.12167>. Accessed: Nov. 15, 2019. doi: 10.1111/raq.12167.

ARRUDA, R.O.M. et al. Spirulina platensis para a produção de biomassa e proteína. Biológico, v.68, p.780-783, 2006. Available from: $<$ http://www.biologico.sp.gov.br/uploads/docs/bio/suplementos/v68 supl/p780-783.pdf>. Accessed: Nov. 15, 2019

BARRIUSO, B. et al. A review of analytical methods measuring lipid oxidation status in foods: a challenging task. European Food Research and Technology, v.236, p.1-15, 2013. Available from: $<$ http://dx.doi.org/10.1007/s00217-012-1866-9>. Accessed: Nov. 15, 2019. doi: 10.1007/s00217-012-1866-9.

GRASSI, T.L.M. et al. Control of the lipid oxidation in Nile tilapia feed. Ciência Rural, v.46, p.1675-1677, 2016. Available from: $<$ http://dx.doi.org/10.1590/0103-8478cr20151612>. Accessed: Nov. 15, 2019. doi: 10.1590/0103-8478cr20151612.
GRASSI, T.L.M. et al. Microbial biomass as an antioxidant for tilapia feed. Aquaculture Research, v.49, p.2881-2890, 2018 Available from: $<$ http://dx.doi.org/10.1111/are.13753>. Accessed: Nov. 15, 2019. doi: 10.1111/are.13753.

LAGUERRE, M. et al. Evaluation of the ability of antioxidants to counteract lipid oxidation: existing methods, new trends and challenges. Progress in Lipid Research, v.46, p.244-282, 2007. Available from: $<$ http://dx.doi.org/10.1016/j.plipres.2007.05.002>. Accessed: Nov. 15, 2019. doi: 10.1016/j.plipres.2007.05.002.

LI, Z.Y. et al. Bioeffect of selenite on the growth of Spirulina platensis and its biotransformation. Bioresource Technology, v.89, p.171-176, 2003. Available from: <http://dx.doi.org/10.1016/ S0960-8524(03)00041-5>. Accessed: Nov. 15, 2019. doi: 10.1016/ S0960-8524(03)00041-5.

MORIST, A. et al. Recovery and treatment of Spirulina platensis cells cultured in a continuous photobioreactor to be used as food. Process Biochemistry, v.37, p.535-547, 2001. Available from: $<$ http://dx.doi.org/10.1016/S0032-9592(01)00230-8>. Accessed: Nov. 15, 2019. doi: 10.1016/S0032-9592(01)00230-8.

PENG, S. et al. Effects of dietary vitamin E supplementation on growth performance, lipid peroxidation and tissue fatty acid composition of black sea bream (Acanthopagrus schlegelii) fed oxidized fish oil. Aquaculture Nutrition, v.15, p.329-337, 2009. Available from: $<$ http://dx.doi.org/10.1111/j.1365-2095.2009.00657.x>. Accessed: Nov. 15, 2019. doi: 10.1111/j.1365-2095.2009.00657.x

PONCE-PALAFOX, J.T. et al. Pigmentation of tilapia (Oreochromis niloticus) with carotenoids from Aztec marigold (Tagetes erecta) in comparison to astaxanthin. Revista Mexicana de Ingenieria Quimica, v.3, p.219-225, 2004. Available from: $<$ https://www.redalyc.org/pdf/620/62030207.pdf>. Accessed: Nov. 15, 2019.

RAN, C. et al. A Comparison of the beneficial effects of live and heat-inactivated baker's yeast on Nile Tilapia: suggestions on the role and function of the secretory metabolites released from the yeast. PLoS One, v.11, e0151207, 2016. Available from: <http:// dx.doi.org/10.1371/journal.pone.0151207>. Accessed: Nov. 15, 2019. doi: 10.1371/journal.pone.0151207.

SOARES, D. G. et al. Avaliação de compostos com atividade antioxidante em células da levedura Saccharomyces cerevisiae. Revista Brasileira de Ciências Farmacêuticas, v.41, p.95100, 2005. Availabre from: <http://dx.doi.org/10.1590/S151693322005000100011>. Accessed: Nov. 15, 2019. doi: 10.1590/ S1516-93322005000100011. 